\title{
Multi-Criteria Decision-Making Model to Support Landfill Prioritization: Methane Risk Assessment
}

\author{
Una Marceta ${ }^{1 *}$, Bogdana Vujic ${ }^{1}$, Zorica Srdjevic ${ }^{2}$, Visnja Mihajlovic ${ }^{1}$, \\ Dragica Radosav ${ }^{1}$ \\ ${ }^{1}$ University of Novi Sad, Technical Faculty “Mihajlo Pupin”, Djure Djakovica bb, Zrenjanin, Serbia \\ ${ }^{2}$ University of Novi Sad, Faculty of Agriculture, Trg Dositeja Obradovica 8, Novi Sad, Serbia
}

Received: 27 February 2020

Accepted: 17 June 2020

\begin{abstract}
Landfilling as the most common type of waste disposal in low income countries causes various environmental issues due to gas emission. Since little attention was paid to air pollution from landfills, due to the lack of appropriate data, the aim of this paper is to establish a model for a landfill prioritization according to the methane risk assessment in developing countries like Serbia. Considering that the landfill methane risks (i.e. emission and atmospheric distribution and dispersion) depends on various parameters (criteria), to accomplish the objective, the authors carried out: a preliminary identification of the key criteria based on the available data, appointed criteria importance by Analytical Hierarchy Processes (AHP), established landfill impact category and proposed the final prioritization of landfills by Compromise Programing (CP) method. The proposed model was successfully tested and applied to eight landfills in South Backa District in the Republic of Serbia. Due to the lack of financial resources, the development of a model for a landfill prioritization according to the methane risk assessment presented in this paper could be a significant foundation for decision-makers in order to establish the priorities for undertaking the necessary control and remedial measures.
\end{abstract}

Keywords: landfill, methane, risk assessment, AHP, CP, air dispersion modelling

\section{Introduction}

An adequate solid waste management is of crucial importance for preventing negative impact of waste on the environment $[1,2]$. Due to its economic advantages, landfilling is still the dominant way of solid waste management [3]. Developing countries most often

*e-mail: una.tasovac@tfzr.rs face problems of environmental degradation because of waste disposal in uncontrolled and non-sanitary landfills. Therefore, a potential risk assessment is of great importance for landfill designing, operating and closing [4].

As a candidate country for European Union (EU) membership, Republic of Serbia has commitment to harmonize its national legislation with EU Directives $[5,6]$, whereas landfilling is a common practice of waste management although it has negative impact on 
the environment: odor, dust, noise, risk of groundwater contamination and landfill gas (LFG) emission [7]. One of the greatest risks from environmental aspect is LFG emission, because it is dominantly composed out of methane $\left(\mathrm{CH}_{4}: 55-60 \% \mathrm{v} / \mathrm{v}\right)$ and carbon dioxide $\left(\mathrm{CO}_{2}\right.$ : $40-45 \% \mathrm{v} / \mathrm{v}$ ), whereby $\mathrm{CH}_{4}$ has 28 times greater global warming potential [8].

Due to the different migration through ground and atmosphere, inadequate LFG management can cause explosions, asphyxiation and can be toxic for people, flora and fauna. It can also cause odors, corrosion and can contribute to greenhouse gas emissions and photochemical smog [9-11]. The landfill characteristics such as size, age, disposed waste type, presence of water and geological conditions are factors that determine the extent of the risk [12].

In the Republic of Serbia there are 160 controlled and 3500 uncontrolled waste disposal sites [13, 14]. Between 5 and $8 \%$ of the total generated amount of the municipal solid waste is recycled [15]. Currently, there are only 10 sanitary landfills at which cca. $4 \%$ of total generated waste amount is being disposed of [13].

Although some of the landfills in the RS have passive degassing system exclusively installed for preventing the hazardous risk (spontaneous fires and explosions), all generated LFGs are released in the atmosphere.

According to the official data of the Serbian Environmental Protection Agency in 2014, emissions from the waste management sector accounted for $4.9 \%$ of the total greenhouse gases (GHG) and that $60.7 \%$ of the GHG emissions consist of the emissions from the solid waste disposal sub-sector. From 2000 to 2014 the share of methane emission in total GHG emission ranged from $11.3 \%$ to $15.3 \%$. In 2014 methane emissions $\left(\mathrm{CH}_{4}\right)$ accounted for $351.39 \mathrm{Gg}$ and $22.6 \%$ of methane was emitted due to solid waste disposal [16].

As a prerequisite for EU membership, one of the most important tasks for the Republic of Serbia is to eliminate non-compliant landfills and to minimize and control emissions from existing waste disposal sites. In order to minimize these impacts, landfills require closure and remediation, but one of the biggest obstacles for solving problems related to waste management in developing countries is lack of financial funds.

When it comes to risk assessment factors for landfill closure and remediation related to landfill gas (i.e. methane) pollution, in the Republic of Serbia the emphasis has been put on its emission potential while little attention has been paid to its distribution in ambient air. Although different risk assessment concepts of methane distribution have been implemented in the developed countries, they are not applicable in the transition countries because of the lack of the necessary data $[11,12,17-19]$.

In that sense, the objective of this study is to propose a model for a landfill prioritization according to the methane risk assessment in developing countries like Serbia.

Since the landfill prioritization related to methane emission, distribution and its impact on the air quality should be based on various parameters (criteria), the authors decided to use Multi-Criteria Decision Making (MCDM) methods. Hence, Analytical Hierarchy Processes (AHP) and Compromise Programing (CP) has been used. The MCDM methods are often used for adequate landfill site selection [20-24] and could be a very useful tool for prioritization and ranking of the polluting landfills in order to undertake necessary control and remedial measures [25].

\section{Material and Methods}

To establish a framework method for landfill prioritization the starting point was collecting and aggregation data on landfills in Serbia.

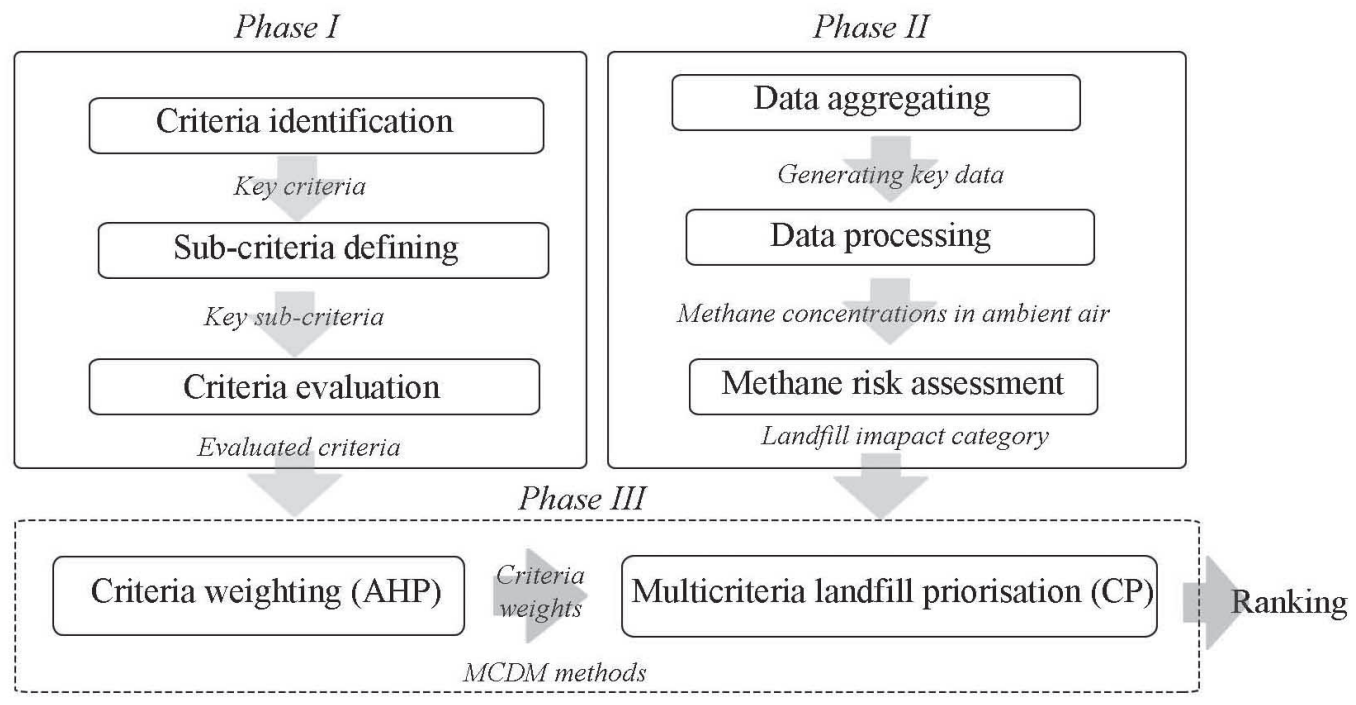

Fig. 1. Conceptual model for landfills prioritization. 
Available data processing and detailed analysis designated two core direction in further research. The first direction was identification of key landfill characteristics (criteria and sub-criteria) that could be of great importance for methane risk assessment. The second direction was landfills categorization according to the impact on air quality and surrounding vulnerabilities. Impact categories were established for each sub-criterion based on the relevant data and by modelling techniques (i.e. for methane emission rate and methane distribution in the air).

The MCDM methods were used for further data processing. Key criteria have been evaluated by experts and weighted by Analytical Hierarchy Process (AHP). And in a final phase, landfill prioritization was accomplished by Compromise Programing (CP).

The framework model for the prioritization and ranking of landfills based on methane risk is given in Fig. 1.

\section{Analytic Hierarchy Process (AHP)}

The AHP method is based on solving a multi criteria problem which is hierarchically structured through alternatives, criteria, sub-criteria and goals (Table 1). The goal is at the top of hierarchy while criteria, sub-criteria and alternatives are on a lower scale of importance. Also, there are cases when it has four or more levels. AHP can be used for individual and group decision making where the methods of analysis and evaluation are the same in both cases while in the case of group AHP application the decision is most often obtained by combining individual grades or priorities $[26,27]$. The decision maker uses a mechanism of partial parity comparison by Satie scale with 1-9 values. It represents a range from equal importance (1) to extreme importance (9). The values 2, 4, 6 and 8 are intermediate values between two adjacent judgments [28]. By mutually comparing the hierarchy elements in pairs, relative weights of the elements at certain level are obtained. The final weights of the alternatives are usually calculated by additive synthesis.

\section{Compromise Programming (CP) Method}

In order to rank and prioritize landfills for remediation based on the defined criteria, the authors used Compromise Programming (CP) method.

The CP method was used for alternative ranking according to which the best alternative should have the shortest distance from the reference point i.e. the ideal solution. The minimization of ideal value proximity is a surrogate of the method of standard maximization of criterion function [26]. The distance measure is the $L_{p}$ metric family as shown in Eq. 1:

$$
L_{p}(i)=\left[\sum_{j=1}^{M} W_{j}^{p}\left|\frac{r_{j}^{*}-r_{i j}}{r_{j}^{*}-r_{j}^{* *}}\right|^{p}\right]^{1 / p}
$$

...where $L_{p}(i)$ is distance metric of $i$-th alternative for the given parameter $p, w_{j}$ is the weight of criterion $j$, and $r_{j}^{*}$ and $r_{j}^{* *}$ are the best and the worst rating values on the set of alternatives of $j$-th criterion. The parameter $p$ indirectly shows the preferences of balancing the criteria $(p=1)$ by the usual squared error effect $(p=2)$ or finding dominant solution $(p=\infty)$.

For the observed problem, the weight factors were determined using the AHP method. Based on the normalized matrix and the integrated weight factors, using CP method with the parameter $p$ set to "2" the final value of multi criteria evaluation i.e. landfill ranking was obtained.

\section{Methane Emission Rate and Dispersion Modelling}

For the purpose of landfill impact categorization, each criterion must be uniquely defined. For the purpose of this research simulation of methane distribution in the ambient air was performed by ADMS Urban software. ADMS Urban is widely used Gaussian dispersion model which simulate a wide range of pollution from various sources [29-31]. Three group of data are used as an input for modeling in ADMS: 1) Ambient related parameters which refer on the geographical configuration of the area where methane is emitted; 2) Meteorological parameters (wind speed and direction, atmospheric stability, precipitation, cloudiness, etc.); 3) Emission related parameters (emission sources, properties of the emitted gas and emission levels). LandGEM 3.02 modelling software was used to calculate the gas emissions levels. This model is a function of two model parameters, methane production potential and first-order decay rate which is associated with waste decomposition $\left(\mathrm{yr}^{-1}\right)$, as shown in Eq. 2 [32]:

$$
Q_{n}=k L_{0} \sum_{i=0}^{n} \sum_{j=0.0}^{0.9} \frac{M_{i}}{10} e^{-k t_{j}}
$$

...where $\mathrm{Q}_{\mathrm{n}}$ is $\mathrm{CH}_{4}$ generation rate $\left(\mathrm{m}^{3} / \mathrm{yr}\right)$ in year $\mathrm{n}$; $\mathrm{k}$ is first-order waste decay rate $\left(\mathrm{yr}^{-1}\right) ; \mathrm{L}_{0}$ is the $\mathrm{CH}_{4}$ generation potential $\left(\mathrm{m}^{3} / \mathrm{Mg}\right) ; \mathrm{M}_{\mathrm{i}}$ is the waste mass placement in year $\mathrm{i}(\mathrm{Mg}) ; \mathrm{j}$ is an intra-annual time increment used to calculate $\mathrm{CH}_{4}$ generation; and $\mathrm{t}$ is time (yr).

\section{Results and Discussion}

\section{Criteria and Sub-Criteria Identification}

The baseline of this research is the identification of landfill characteristics that are important for the methane impact on the environment. Eight indicators (sub-criteria) were selected by the experts and later grouped into the four groups of criteria. The data 
used for key sub-criteria identification is later used for landfill impact category determination (presented in Landfill impact categorisation chapter).

\section{Criteria: SOURCE EMISSION POTENTIAL}

The first criterion is related to source emission potential. Methane emission potential from landfill depends on several factors that were in this case taken as sub-categories:

Landfill type (C1) - There are only 10 landfills in Serbia that meet the criteria defined by the EU Directive (sanitary). Other landfills, where more than $80 \%$ of generated waste is disposed, have certain characteristics of sanitary (active controlled) landfill (waste weighting, installed degasification system and the inert layer application). The rest of the disposal sites could be categorized as a non-controlled disposal site (active non controlled).

Waste amount/landfill size (C2) - The landfill size i.e. the amount of disposed waste affects the amount of generated methane. Data on dimensions and volume of landfill in the Republic of Serbia are not the reliable because they are based on estimation and there is no relevant technical documentation for many landfills [33]. The average waste production in the Republic of Serbia is $0.87 \mathrm{~kg} / \mathrm{capita} /$ day [34]. According to available data on landfills volume there are three types of landfills: large (more than $100,000 \mathrm{~m}^{3}$ ), medium $\left(50,000-100,000 \mathrm{~m}^{3}\right)$ and small (less than $50,000 \mathrm{~m}^{3}$ ) [13].

Landfill age (C3) - Since the degradation of waste is determinate by the age, this criterion primarily refers to waste decomposition phase (there are four phases: Aerobic; Anaerobic Non-Methanogenic; Anaerobic Methanogenic Unsteady; and Anaerobic Methanogenic Steady.) Landfills typically generate significant amounts of gas within the period of one to three years. The gas generation maximums are reached five to seven years after the waste has been deposited, and 20 years after disposal generation of landfill gas is minimal and traceable [35].

The composition of waste (C4) - Variations in the morphological composition of waste can occur at the local level depending on several factors: economic development and urban characteristics of the municipality as well as the age and educational background of inhabitants. About 50\% of generated waste in Serbia contains biodegradable waste (garden waste or food) [36].

\section{Criteria: THE LANDFILL INFRASTRUCTURE}

Knowing the migration phenomenon and the path of landfill gas through the cracks, its emission into the atmosphere and further dispersion due to local meteorological conditions is of crucial importance for the consideration of potential environmental and human health risks.
Criterion $\mathrm{C} 1$ has been used in order to establish the categories of this group of criteria. Since the majority of landfills in Serbia are partially controlled, the basic flaws mostly refer to improper landfill bottom lining system, degradation system and the type of landfill covering material, these criteria was conceived as follows:

Bottom landfill lining system (C5) - Synthetic or natural impermeable bottom liner of the landfill (foil or clay) prevents gas penetration below the landfill level and improves the vertical distribution i.e. the emission into the atmosphere. Contrastively, the horizontal landfill gas migration was improved by permeable liners so the landfill gas could penetrate and accumulate in the lower parts of the surrounding objects [37].

Therefore, if there is no landfill gas collection system, each type of the lining system carries a certain risk.

Landfill cover (C6) - Covering and compacting is important for degradation of waste [38]. The usual practice in Serbia is usage of the low-cost covers that includes soil, compost and alternatively no cover.

\section{Criteria: VULNERABILITIES}

The third criterion is related to landfills impact on the environment and human health. Areas where there is a potential landfill impact on surroundings are defined as buffer zones.

Buffer zones (C7). These zones are most defined at distances from $200 \mathrm{~m}$ to $500 \mathrm{~m}$. According to EPA [39] when the distances are greater than $500 \mathrm{~m}$, the risks to the environment is low. If there are facilities or their construction is planned within buffer zones, a risk assessment of the harmful effects of landfill gas and odor is required.

In the Republic of Serbia, the size of the buffer zone and obligatory risk assessment in these zones are not directly prescribed. However, Regulation on waste landfilling [40] which refers to the construction of new landfills defines the distances between the external boundaries of the landfill site:

1. Not less than $500 \mathrm{~m}$ from the nearest facility of the populated area, where people live.

2. At least $300 \mathrm{~m}$ from detached houses not located in settlements and other constructions in which people work or live but only if they are sheltered so the landfill cannot be seen.

According to Serbian Environmental Protection Agency (SEPA) in the territory of the Republic of Serbia, $7.3 \%$ landfills are located at distances less than $100 \mathrm{~m}$ from the settlements, $30.5 \%$ at distances from $100 \mathrm{~m}$ to $500 \mathrm{~m}$ and $62.2 \%$ at distances greater than $500 \mathrm{~m}$ from the settlement. Considering that all landfills in Serbia are located around settlements we could say that the majority of population could be affected by pollution from the landfill [13]. 


\section{Criteria: POTENTIAL METHANE CONCENTRA- TION IN THE AMBIENT AIR}

Almost all methane generated in landfills in Serbia are directly released into the atmosphere. Primarily, landfills use a passive degassing system mostly because of explosion and fire prevention. The use of landfill gas is almost non-existing, and the gas is directly emitted into the atmosphere. Besides the emission from the existing gas well, fugitive gas emission should not be neglected. In the Republic of Serbia, there are no monitoring of methane concentration in ambient air. Therefore, simulation dispersion models can be used for relative assessment of distribution and methane concentration in ambient air [9].

Methane concentration (C8). There is no defined limit value for methane in ambient air. Exemption are very high concentration of 500,000 ppm that can cause asphyxiation and maximum recommended safe methane concentration for workers during an 8-hour period of 1,000 ppm [41].

\section{Criteria Evaluation and Weighting}

The Analytic Hierarchy Process method was used for criteria evaluation and weighting. The entire AHP was not applied completely in the case of this study. Standard AHP methodology requires evaluation of criteria versus goal and alternatives versus each of criteria (in that case we could say that AHP was applied completely). Here we used AHP just to evaluate importance of criteria vs goal and calculate weights of criteria. Those weights were then used as input in CP method in order to find ranking of alternatives (since numerical data reflecting the performance (impact) of alternatives vs criteria were given, $\mathrm{CP}$ was found more suitable for ranking than AHP). In this case, the structure included four criteria groups with eight subcriteria given in Table 1.

Five experts (E1-E5) with significant experience in the field of the waste management, participated in the evaluation of criteria and sub-criteria. The evaluation was carried out using a questionnaire consisting of two parts. The first one included an explanation of the research and described criteria while in the second part the questionnaire included the evaluation matrices (Saaty's scale 1-9).

Results of the expert judgment are presented in the Table 2 .

The three experts individually claimed that criterion C8 (methane concentration) is the most significant in assessing the methane risk. Opposite of that, one expert claimed that the most important indicator is $\mathrm{C} 1$ (landfill type) and one of the experts considered C4 (waste composition) as the most important criteria (Table 2).

Considering the normalized geometrically averaged weights of criteria, the experts estimated that subcriteria C8 (methane concentration) with the average weight of 0.270 is the most significant. The subcriteria C4 (waste composition - 0.715) and C1 (landfill

Table 1. Hierarchal structure of alternatives, sub-criteria, criteria and goal.

\begin{tabular}{|c|c|c|c|c|}
\hline Goal & \multicolumn{4}{|c|}{ Ranking the landfills according methane risk } \\
\hline Criteria & $\begin{array}{l}\text { Source emission } \\
\text { potential }\end{array}$ & The landfill infrastructure & Vulnerabilities & $\begin{array}{l}\text { Potencial methane concentration in } \\
\text { the ambient air }\end{array}$ \\
\hline \multirow{4}{*}{ Sub criteria } & Landfill type & & \multirow{4}{*}{ Buffer zones } & \multirow{4}{*}{ Methane concentrations } \\
\hline & Landfill size & Dotom immg system & & \\
\hline & Landfill age & \multirow{2}{*}{ Landfill cover } & & \\
\hline & Waste composition & & & \\
\hline Alternatives & Landfill 1 & Landfill 2 & Landfill 3 & Landfill n \\
\hline
\end{tabular}

Table 2. Results of the expert judgment presented in the form of the weights of the criteria.

\begin{tabular}{|c|c|c|c|c|c|c|c|c|}
\hline \multirow{2}{*}{$\begin{array}{c}\text { Criteria/ } \\
\text { Expert }\end{array}$} & \multicolumn{9}{|c|}{ Weights } \\
\cline { 2 - 11 }$y$ & $w_{1}$ & $w_{2}$ & $w_{3}$ & $w_{4}$ & $w_{5}$ & $w_{6}$ & $w_{7}$ & $w_{8}$ \\
\hline E1 & 0.113 & 0.181 & 0.076 & 0.116 & 0.129 & 0.075 & 0.104 & 0.207 \\
\hline E2 & 0.09 & 0.024 & 0.093 & 0.229 & 0.023 & 0.056 & 0.039 & 0.446 \\
\hline E3 & 0.027 & 0.034 & 0.131 & 0.206 & 0.046 & 0.084 & 0.032 & 0.440 \\
\hline E4 & 0.034 & 0.107 & 0.177 & 0.230 & 0.171 & 0.071 & 0.056 & 0.154 \\
\hline E5 & 0.461 & 0.097 & 0.111 & 0.096 & 0.016 & 0.053 & 0.062 & 0.104 \\
\hline Aggregated & 0.145 & 0.089 & 0.117 & 0.175 & 0.077 & 0.068 & 0.059 & 0.270 \\
\hline
\end{tabular}




\begin{tabular}{|c|c|c|c|c|c|}
\hline 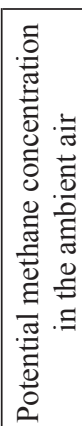 & $\ddot{0}$ & 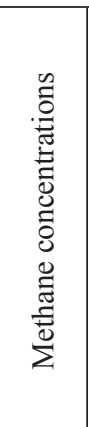 & 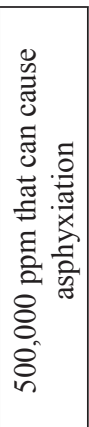 & 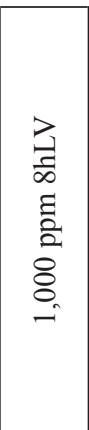 & 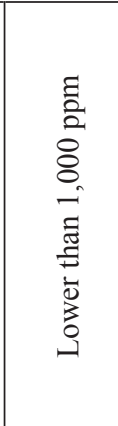 \\
\hline 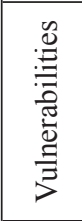 & $\hat{U}$ & 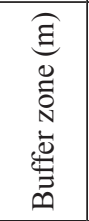 & $\begin{array}{l}\Xi \\
\stackrel{\Xi}{\mathrm{V}}\end{array}$ & 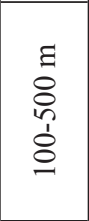 & $\begin{array}{l}\Xi \\
\stackrel{0}{0} \\
\stackrel{\Lambda}{n}\end{array}$ \\
\hline $\begin{array}{l}0 \\
\stackrel{\Xi}{0} \\
\text { E }\end{array}$ & 8 & 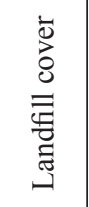 & $\overline{\bar{\delta}}$ & $\begin{array}{l}\vec{b} \\
\text { oे } \\
\text { 言 } \\
\text { on }\end{array}$ & $\begin{array}{l}\overline{0} \\
\stackrel{0}{0} \\
\dot{z}\end{array}$ \\
\hline 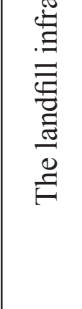 & 3 & 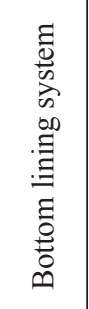 & $\overline{0}$ & 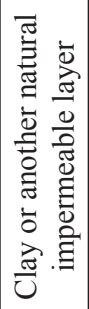 & 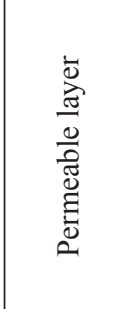 \\
\hline \multirow{4}{*}{ 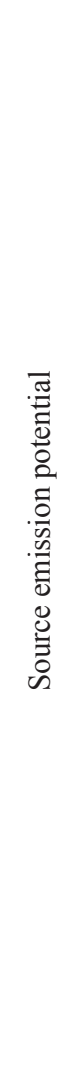 } & త & 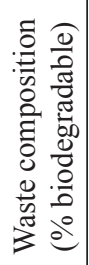 & 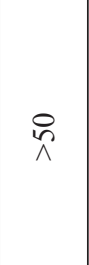 & $\stackrel{\mathscr{V}}{V}$ & 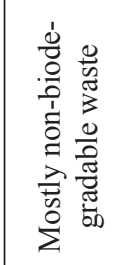 \\
\hline & $\tilde{\theta}$ & 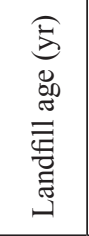 & $\stackrel{\circ}{\stackrel{1}{n}}$ & $\begin{array}{l}\stackrel{T}{~} \\
\text { ல̂ }\end{array}$ & $\stackrel{\wedge}{\wedge}$ \\
\hline & I & 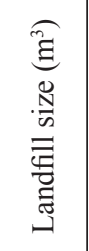 & $\begin{array}{l}8 \\
\stackrel{8}{\circ} \\
\frac{8}{1}\end{array}$ & $\begin{array}{l}8 \\
8 \\
8 \\
1 \\
8 \\
8 \\
8 \\
\dot{8}\end{array}$ & $\begin{array}{l}8 \\
\& \\
\stackrel{8}{n}\end{array}$ \\
\hline & $\vec{U}$ & $\begin{array}{l}\text { 号 } \\
\text { 焉 } \\
\text { 恶 }\end{array}$ & $\begin{array}{l}\bar{\Xi} \\
\overline{0} \\
0 \\
0 \\
0 \\
0 \\
0 \\
0 \\
0 \\
.0 \\
0 \\
0\end{array}$ & 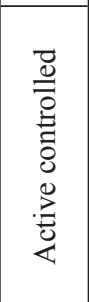 & 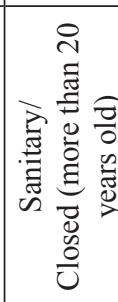 \\
\hline : & 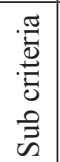 & 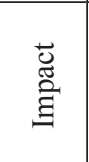 & $\frac{0}{0}$ & $\underset{\sum}{\sum}$ & $\begin{array}{l}\text { 号 } \\
\text { ż } \\
\Sigma\end{array}$ \\
\hline
\end{tabular}

type -0.415$)$ were evaluated as slightly less relevant. Also, the experts said that sub-criteria C5 (bottom lining system) and C6 (landfill cover), in the frame of landfill infrastructure criterion, have the approximate weight values (C5 - 0.077, C6 - 0.068). Vulnerabilities criterion with a single defined sub-criterion, buffer zone (C7) is the least important (0.059) (Table 2).

\section{Landfill Impact Category}

The field data, experience of the experts and other official data (presented in Criteria and sub-criteria identification chapter) could be of interest for landfill categorization according to criteria $\mathrm{C} 1$ to $\mathrm{C}$. In addition, for the landfill categorization according to $\mathrm{C} 8$ criterion, field measurements or different calculation methods as well as modeling of emission levels as well as modelling of ambient concentration may be used. In this study modelling softwares LandGEM 3.02 for methane emission rate and ADMS Urban for methane air distribution were applieAccording to the landfill characteristics the landfill impact category was defined as major, medium and minor (Table 3).

For example, the Major impact category includes landfills that have the greatest emission potential because the waste is still being disposed there and methane emission control is not being carried out, so it is freely emitted into the atmosphere either through gas wells or fugitive emission. Also, it includes landfills that contain great waste amount (over 100,000 $\mathrm{m}^{3}$ ), that are in the most intensive methanogenic phase (from 5 to 10 years) as well as landfills at which disposed waste contains more than $50 \%$ of biodegradable waste which greatly contributes to methane production.

\section{Case Study}

The proposed framework method for landfill prioritization according methane risk assessment was performed on controlled landfills in South Backa District located in the Province of Vojvodina. The district covers $4,016 \mathrm{~km}^{2}, 12$ municipalities with 77 populated areas and 615,371 inhabitants. The population density is 93.6 people per $\mathrm{km}^{2}$. The Fig. 2 shows the location of South Backa District in the Republic of Serbia as well as the photographs and satellite images of some landfills. In this paper, eight landfills were analyzed according to the criteria. The selected landfills are located in Novi Sad, Temerin, Vrbas, Backa Palanka, Beocin, Backi Petrovac, Srbobran and Zabalj.

Since the criteria weights and landfill impact categories were already defined, in this stage, field data on selected landfills were processed in order to categorize each landfill according to its impact.

\section{Landfill Impact Categorization}

Given that the national landfill register in the Republic of Serbia is still in the developing stage, the 


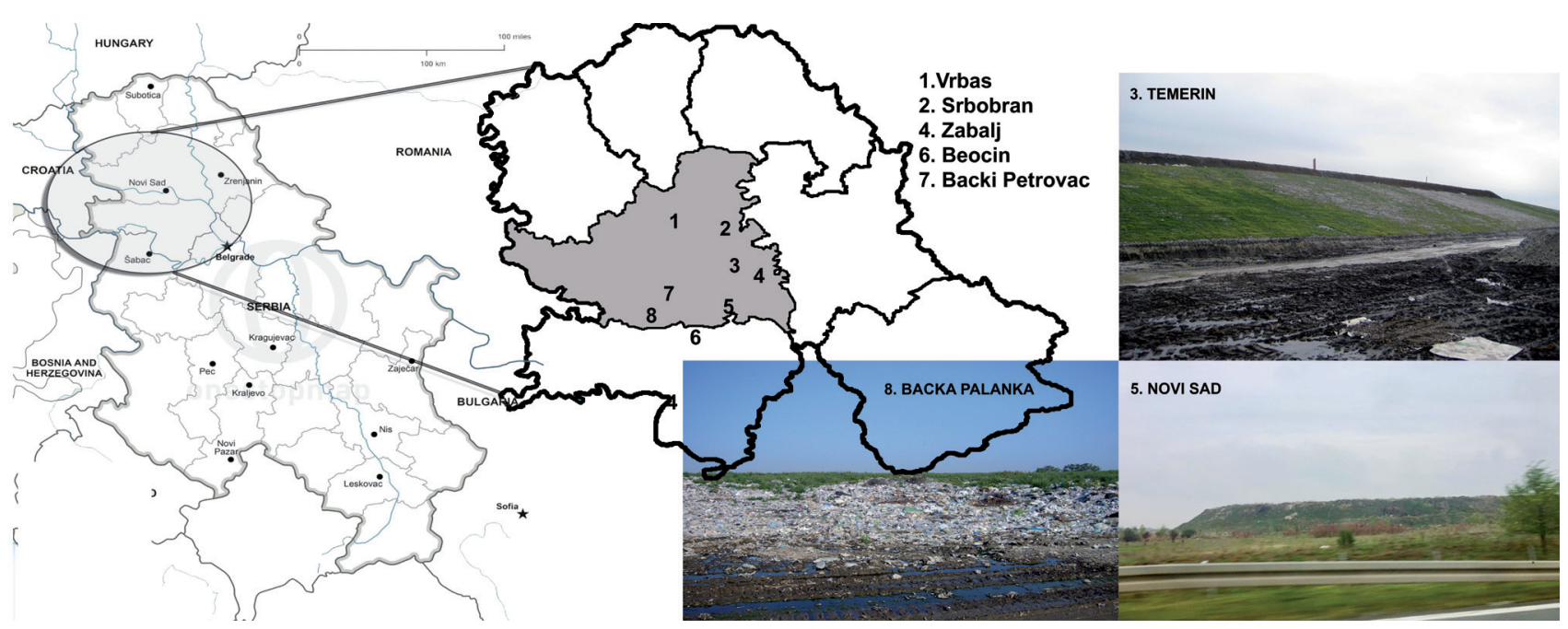

Fig. 2. Location of the selected landfills.

available data on criteria $\mathrm{C} 1$ to $\mathrm{C} 7$ were collected from the field, experts' experience and the official data of the Environmental Protection Agency of the Republic of Serbia [13, 42-44].

The following text shows data analysis for each selected landfill by criteria.

Landfill type (C1) - By data analysis on landfills for this criteria, it was found that only two out of eight active landfills were controlled (Novi Sad and Temerin) while the other active landfills could be classified as uncontrolled because they do not have the basic control elements for the amount of disposed waste and the degassing system.

Waste amount/landfill size (C2) - According to the landfill size i.e. the amount of disposed waste $\left(\mathrm{m}^{3}\right), 4$ out of 8 landfills could be classified as smaller landfills (to $50,000 \mathrm{~m}^{3}$ ). Those are Backi Petrovac $\left(31,800 \mathrm{~m}^{3}\right)$, Beocin $\left(30,300 \mathrm{~m}^{3}\right)$, Zabalj $\left(7,260 \mathrm{~m}^{3}\right)$ and Srbobran $\left(5,050 \mathrm{~m}^{3}\right)$. Two landfills were classified as medium-sized landfills (from 50,000 to $100,000 \mathrm{~m}^{3}$ ): Vrbas $\left(99,750 \mathrm{~m}^{3}\right)$ and Temerin $\left(74,000 \mathrm{~m}^{3}\right)$. Novi Sad $\left(1,967,700 \mathrm{~m}^{3}\right)$ is the biggest of the considered landfills.

The composition of waste (C3) - According to the waste composition at seven landfills, it was identified that disposed waste contains up to $50 \%$ of biodegradable waste.

Landfill age (C4) - Almost all landfills are over 20 years old, except the one in Srbobran which is in the middle age category (from 10 to 20 years).

Landfill infrastructure (C6) - It was found that all observed landfills have permeable surface except the one in Temerin where the bottom was hydro-isolated during the remediation. As for the landfill cover subcriterion, the half of the landfills is covered with soil while rest of the landfills do not have any cover (Novi Sad, Backa Palanka, Temerin and Vrbas).

Vulnerabilities (C7) - criterion includes the distances of the closest objects (residential and business). It was found that the range of distance stands from $100 \mathrm{~m}$ (in Novi Sad where is material recovery facility (MRF) where workers work every day) to $2 \mathrm{~km}$ (Backa Palanka).

Methane concentration (C8) - The assessment of criterion C8 was carried out using ADMS Urban software, data demanding simulation tool. Data used as an input for modelling included:

1. Emission related parameters:

- Emission sources. Landfills model are set as volume sources of fugitive emission that are constantly emitted with no significant emission velocity. An average adopted temperature of emitted methane was set up to $30^{\circ} \mathrm{C}$ [45];

- Emission levels. Given that there are no official data on previous waste amount on researched landfills, waste generation rate $\mathrm{kg}$ capita $^{-1 \mathrm{y}-1}$ was used as a constant. The influence of methane oxidation variation in soil cover is assessed with 0.2 and 0.5 oxidation factors and the worst scenario of methane production was used. Hence, depending on the landfills, the calculated methane emission (by LandGem) was in the range from 239.8 to 11,420 $\mathrm{Mg} / \mathrm{god}$.

2. Meteorological parameters (wind speed (WS), wind direction (WD), temperature (T), Relative humidity $(\mathrm{RH})$ and Cloud cover $(\mathrm{Cl})$ ): Modeling was performed for prevailing meteorological conditions at all locations [46].

3. Ambient related parameters refer to geographical configuration of the area of emitted methane. A real environment for simulation of each landfill area was simulated in ADMS mapper program. Modelling domain was defined as an area of $1,000 \times 1,000 \mathrm{~m}(\mathrm{X}, \mathrm{Y})$, with the resolution of 31 points in each direction. The nearest facilities or houses are defined as a vulnerable objects/receptor. 3D Simulation of real environment for landfill in Novi Sad is presented on Fig. 3.

The methane concentration levels had been obtained in the closest facilities around the landfill as a result of ADMS software application. The numerical modelling 


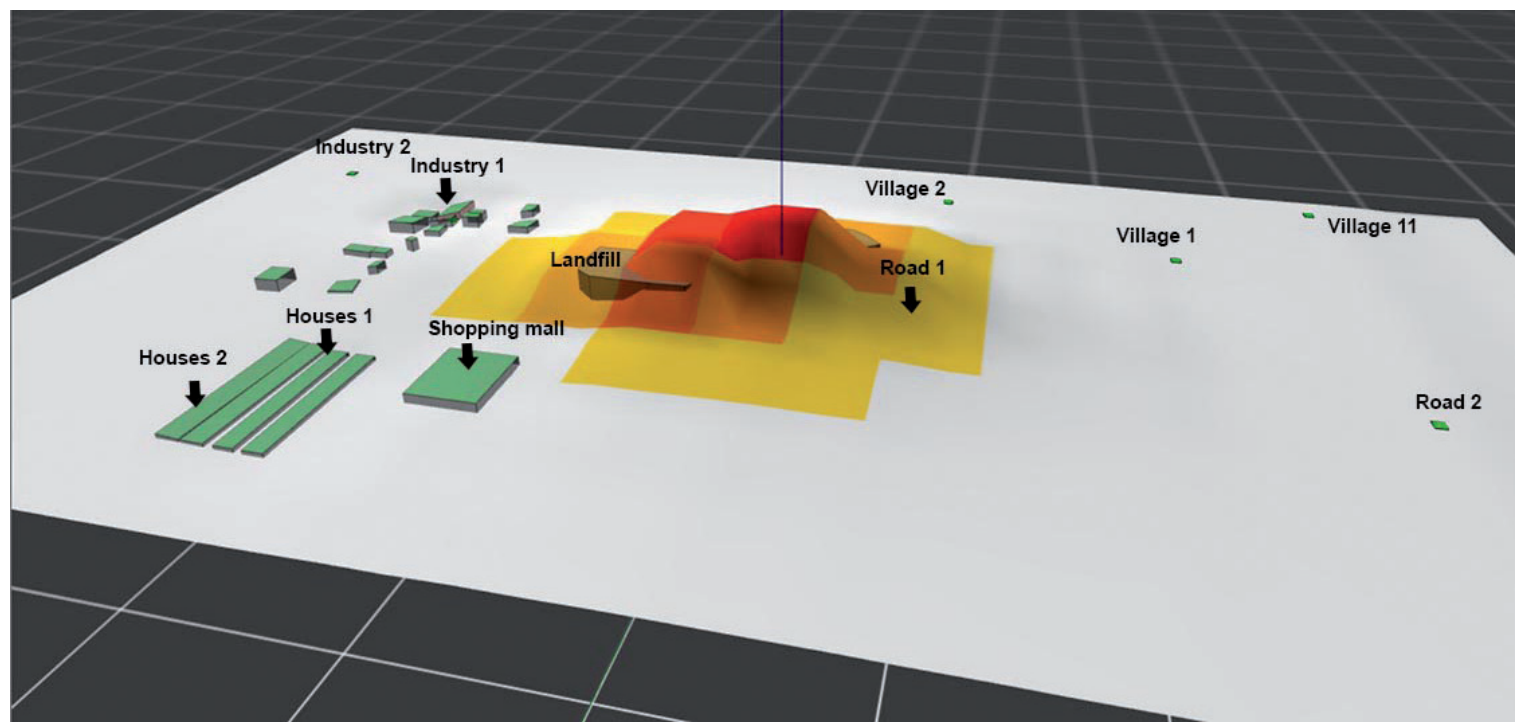

Fig. 3. 3D concentration contour plot for landfill in Novi Sad.

results were then analyzed and methane concentrations in ambient air as well as the vulnerable zones around the landfill were determined. The highest methane concentration which accounted for $800 \mu \mathrm{g} / \mathrm{m}^{3}$ was modelled in the vicinity of the landfill in Novi Sad which is the largest landfill and has facilities at the smallest distances compared to other landfills (100 m). The lowest methane concentration was modelled in the vicinity of the landfill in Backi Petrovac i.e. the specific point that is located at $1,000 \mathrm{~m}$ distance.

The analysis of the landfill data showed that the landfills tested in this paper have similar characteristics in most of the defined criteria $(\mathrm{C} 1, \mathrm{C} 3, \mathrm{C} 4, \mathrm{C} 5$ and C6). The differences among landfills are the greatest in criteria C2 (landfill size) and consequently C8 (methane concentration) as well as in criteria C7 (vulnerabilities).

\section{Multi-Criteria Landfill Prioritization}

For multicriteria landfill prioritization, criteria weights and landfills impact categorization was

Table 4. Final landfill ranking.

\begin{tabular}{|c|c|}
\hline Landfill location & Rank \\
\hline Novi Sad & 1 \\
\hline Backa Palanka & 2 \\
\hline Vrbas & 3 \\
\hline Temerin & 4 \\
\hline Backi Petrovac & 5 \\
\hline Beocin & 6 \\
\hline Zabalj & 7 \\
\hline Srbobran & 8 \\
\hline
\end{tabular}

processed according to the $\mathrm{CP}$ method that identified the distances of all alternatives (landfills) from the reference point, where the smallest distance value is given the highest rank. Final ranking of landfills according to the significance of methane effect is given in Table 4.

The results of final ranking revealed that the most important criteria, $\mathrm{C} 8$ and $\mathrm{C} 4$, are consequently related since the methane generation amount and its potential emission into the air depends on waste composition. Although experts did not highlight criteria C2 (landfill size) as the most significant criteria, the results of the case study clearly indicated its direct influence on final ranking.

Considering the great similarity in relevant landfill characteristics, the impact of other criteria regardless of their weights did not seem as important in the final landfill ranking. The obtained results indicated the need to reassess the importance of criteria $\mathrm{C} 1, \mathrm{C} 3, \mathrm{C} 4, \mathrm{C} 5$ and $\mathrm{C} 6$ through further research that would include various landfill types as well as the higher number of experts. Also, the criterion $\mathrm{C} 7$ should be additionally elaborated by defining types of vulnerable facilities in buffer zones. Additionally, concentration ranges should be revised because the defined concentration ranges within $\mathrm{C} 8$ are too high in comparison to the modelled concentrations.

\section{Conclusions}

In the Republic of Serbia, as a developing country, a waste management system has not yet been fully implemented. Waste management include only waste collection, transport and disposal, without waste treatment, to uncontrolled landfills that do not comply with minimum requirements criteria and standards for the disposal of waste. 
Resent landfill risk assessment models are based on the landfill ranking according to the pollution caused by leachate whereas less attention is given to the impact of landfill gas on air quality and consequently on surrounding population. Therefore, the authors proposed a method for landfill prioritization. The method is based on methane risk assessment through key criteria based on the available data.

As a country that has applied for EU membership, Serbia must approach the unique systematic solution of waste management issues. Landfilling as a dominant way of waste management and the fact that the sanitary and safe waste treatment requires additional financial investments, the landfills closure and after-care need to be given high priority in national environmental agenda as well as priority in terms of distribution of potential financial resources.

The framework method presented in this paper can be used as a decision-making tool in setting the priorities for future landfills' closure. In developing countries, where data on methane emission are difficult to access or unavailable, proposed method and defined criteria and sub-criteria is step forward to development of waste management system that does not harm the environment and human health.

\section{Conflict of Interest}

The authors declare no conflict of interest.

\section{References}

1. DI FELICE P. Integration of Spatial and Descriptive Information to Solve the Urban Waste Accumulation Problem. Procedia - Social and Behavioral Sciences, 147, 182, 2014.

2. GHIANI G., LAGANÀ D., MANNI E., TRIKI C. Capacitated location of collection sites in an urban waste management system. Waste Management, 32, 1291, 2012.

3. DURMUSOGLU E., TASPINAR F., KARADEMIR A. Health risk assessment of BTEX emissions in the landfill environment. Journal of Hazardous Materials, 176, 870, 2010.

4. VOSOOGH A., BAGHVAND A., KARBASSI A., NASRABADI T. Landfill Site Selection Using Pollution Potential Zoning of Aquifers by Modified DRASTIC Method: Case Study in Northeast Iran. Iran J Sci Technol Trans Civ Eng, 41, 229, 2017.

5. EC Council Directive 1999/31/EC of 26 April 1999 on the landfill of waste. https://eur-lex.europa.eu/LexUriServ/ LexUriServ.do?uri=CELEX:31999L0031:EN:HTML

6. EC Council Decision 2003/33/EC establishing criteria and procedures for the acceptance of waste at landfills pursuant to article 16 of and Annex II to Directive 1999/31/EC. Official Journal of the European Union L 11, 27. https:// eur-lex.europa.eu/LexUriServ/LexUriServ.do?uri=OJ:L:20 03:011:0027:0049:EN:PDF

7. HAN D., TONG X., CURRELL M.J., CAO G., JIN M., TONG C. Evaluation of the impact of an uncontrolled landfill on surrounding groundwater quality, Zhoukou, China. J Geochem Explor, 136, 24, 2014.

8. STOCKER T.F., QIN D.H., PLATTNER G.K., TIGNOR M.M.B., ALLEN S.K.,BOSCHUNG J., NAUELS A., XIA Y., BEX V., MIDGLEY P.M. Climate Change 2013: the Physical Science Basis. Contribution of Working Group I to the Fifth Assessment Report of the Intergovernmental Panel on Climate Change. CambridgeUniversity Press, Cambridge, United Kingdom and New York, NY, USA, 2013.

9. KUMAR A., DATTA M., NEMA A.K., SINGH R.K., GURJAR B.R. Improved Rating System for Hazard Assessment Related to Subsurface Migration of Landfill Gas from Municipal Solid Waste Landfills and Dumps. J. Hazard. Toxic Radioact. Waste, 22 (3), 04018003, 2018.

10. STAINES A., CROWLEY D., BRUEN M., O'CONNOR P. Public health and landfill sites. Project Report. Department of Public Health, Eastern Regional Health Authority, Department of Public Health Medicine and Epidemiology, University College Dublin, 2004.

11. EPA Victoria. Siting, design, operation and rehabilitation of landfills. Publication 788.3 Authorised and published by Environment Protection Authority Victoria, 2015.

12. EPA CODE OF PRACTICE. Environmental Risk Assessment for Unregulated Waste Disposal Sites. Environmental Protection Agency, 2007.

13. SEPA, RS Ministry of Environmental Protection, Environmental Protection Agency. Waste management in RS from 2011 to 2017 year, Belgrade, 2018.

14. STANISAVLJEVIĆ N., UBAVIN D., BATINIĆ B., FELLNER J., VUJIĆ G. Methane emissions from landfills in Serbia and potential mitigation strategies: a case study. Waste Management \& Research, 10, 1095, 2012.

15. Economic and Trade Office. Flanders Investment \& Trade Market Survey. Solid waste sector in serbia - overview. Embassy of Belgium, Belgrade, 2017.

16. RS Ministry of Environmental Protection. The Second National Report - Communication of the Republic of Serbia towards the UNFCCC, 2017. http://www. klimatskepromene.rs/wp-content/uploads/2017/12/Drugiizvestaj-o-promeni-klime-SNC_Srbija.pdf

17. EPA 969/12: Information sheet, Landfill gas and development near landfills-advice for planning authorities and developers, 2012.

18. EPD TR8/97 Landfill Gas Hazard Assessment Guidance Note. Waste Facilities Development Group, Environmental Protection Department, Hong Kong Government, 1997.

19. Golder Associates (NZ). Small landfill closure criteria risk assessment for small closed landfills, 2002.

20. JAMSHIDI A., KAZEMIJAHANDIZI E., ALLAHGHOLI L., MONAVARI S. M., TAJZIEHCHI S., HASHEMI A., MOSHTAGHIE M., JAMSHIDI M. Landfill Site Selection: a Basis Toward Achieving Sustainable Waste Management. Polish Journal of Environmental Studies, 24 (3), 1021, 2015

21. HUSSIN W., KABIR S., DIN M., JAAFAR W. Modeling landfill suitability based on multi-criteria decisionmaking method. Interdisciplinary Themes Journal, 2 (1), 20, 2010.

22. EL ALFY Z., ELHADARY R., ELASHRY A. Integrating GIS and MCDM to Deal with Landfill Site Selection. International Journal of Engineering \& Technology IJETIJENS, 10 (6), 33, 2010.

23. ZELENOVIĆ VASILJEVIĆ T., SRDJEVIĆ Z., BAJČETIĆ R., VOJINOVIĆ MILORADOV M. GIS and the Analytic Hierarchy Process for Regional Landfill Site Selection 
in Transitional Countries: A Case Study From Serbia. Environmental Management, 49, 445, 2012.

24. ERSOY H., BULUT F. Spatial and multi-criteria decision analysis-based methodology for landfill site selection in growing urban regions. Waste Management \& Research, 27, 489, 2009.

25. UBAVIN D., AGARSKI B., MAODUS N., STANISAVLJEVIC N., BUDAK I. A Model for Prioritizing Landfills for Remediation and Closure: A Case Study in Serbia. Integrated Environmental Assessment and Management, 14 (1), 105, 2018.

26. SRĐEVIĆ B., SRĐEVIĆ Z., ZORANOVIĆ T. PROMETHEE, TOPSIS and CP in multi-criteria decision making in agriculture [In Serbian]. Letopis naučnih radova, 26 (1), 5, 2002.

27. BLAGOJEVIC B., SRDJEVIC B., SRDJEVIC Z., ZORANOVIC T. Heuristic aggregation of individual judgments in AHP group decision making using simulated annealing algorithm. Information Sciences, 330, 260, 2016.

28. SAATY T.L. Multicriteria Decision Making: The Analytic Hierarchy Process. Pittsburgh, PA: RWS Publications, 1980.

29. CERC, ADMS-Urban User Guide, Version 1.6, 2001.

30. DĖDELE் A., MIŠKINYTE் A. The statistical evaluation and comparison of ADMS-Urban model for the prediction of nitrogen dioxide with air quality monitoring network. Environ Monit Assess, 187, 578, 2015.

31. VUJIC B., MARCETA U., MIHAJLOVIC V., DJURIC A. Modelling landfill methane distribution into the ambient air: Case study of Novi Sad. Reciklaza i odrzivi razvoj, $\mathbf{1 0}$ (1), 9, 2018

32. USEPA. Landfill Gas Emissions Model (LandGEM) Version 3.02 User's Guide, EPA-600/R-05/047 U.S. Environmental Protection Agency, Office of Research and Development and Clean Air Technology Center, 2005.

33. University of Novi Sad, Faculty of Technical Sciences, Department of Environmental Engineering. Determination of waste composition and estimation of quantity in order to define strategy of secondary raw materials management within the framework of sustainable development of the Republic of Serbia, [In Serbian] 2009.

34. VUJIĆ G., BATINIĆ B., STANISAVLJEVIĆ N., UBAVIN D., ŽIVANČEV M. Waste management in Serbia, status quo and strategic framework. Reciklaza i odrzivi razvoj, 4, 14, 2011.
35. FARQUHAR G.J., ROVERS F.A. Gas production during refuse decomposition. Water Air Soil Pollution, 2, 483, 1973.

36. BAJIĆ B.Ž., DODIĆ S.N., VUČUROVIĆ D.G., DODIĆ J.M., GRAHOVAC J.A. Waste-to-energy status in Serbia. Renewable and Sustainable Energy Reviews, 50, 1437, 2015.

37. ROSQUIST H., LEROUX V., DAHLIN T., SVENSSON M., LINDSJÖ M., MÅNSSON C-H., JOHANSSON S. Mapping landfill gas migration using resistivity monitoring. Waste and Resource Management, 164 (1), 3, 2011.

38. SCHEUTZ C., KJELDSEN P., BOGNER J.E., DE VISSCHER A., GEBERT J., HILGER H.A., SPOKAS K. Microbial methane oxidation processes and technologies for mitigation of landfill gas emissions. Waste Management and Research, 27 (5), 409, 2009.

39. EPA Victoria. Draft guideline, Assessing planning proposals near landfills, 2016.

40. Official Gazette of RS no 92/2010, Available online: Regulation on waste landfilling http://extwprlegsl.fao.org/ docs/pdf/srb105180.pdf

41. ATIA A. Methane Safety, AGRI-Facts, Practical information for Albertas Agriculture Industry, Alberta, 2004.

42. Regional Waste Management Plan for the City of Novi Sad and the Municipalities of Backa Palanka, Backi Petrovac, Beocin, Zabalj, Srbobran, Temerin and Vrbas. ("Official Gazette of the City of Novi Sad", No.26/12 and Official Gazettes of all these municipalities)

43. NRIZ GIS SEPA. Available online: http://www.nrizgis. sepa.gov.rs/NRIZGIS/index.html. (accessed 18 March 2019).

44. Geoportal of the APV. Available online: https://geoportal. vojvodina.gov.rs/geoportal $/ \% \mathrm{D} 0 \% \mathrm{~B} 3 \% \mathrm{D} 0 \% \mathrm{~B} 8 \% \mathrm{D} 1 \% 81$. (accessed on 18 March 2019).

45. FROLA C., DE ROZE D. Landfill Gas Operation and Maintenance Manual of Practice. Solid Waste Association of North America, Sylver Spring, SAD, 1997.

46. RHSS, Republic Hydrometeorological Service of Serbia, Yearbook, 2016. Available online: http://www.hidmet. gov.rs/ciril/meteorologija/klimatologija_godisnjaci.php. (accessed 4 February 2019). 